\title{
MODEL PENGEMBANGAN KETAHANAN PANGAN BERBASIS PISANG MELALUI REVITALISASI NILAI KEARIFAN LOKAL
}

\author{
MOCH. AGUS KRISNO BUDIYANTO \\ Program Studi Pendidikan Biologi FKIP Universitas Muhammadiyah Malang \\ E-mail: aguskrisno@yahoo.co.id
}

\begin{abstract}
ABSTRAK
Penelitian ini bertujuan untuk menemukan "Model Pengembangan Ketahanan Pangan Berbasis Pisang dengan Revitalisasi Nilai Kearifan Lokal". Model ini dapat digunakan sebagai dasar untuk merumuskan kebijakan publik dan upaya edukasi dan advokasi publik dalam bidang pangan untuk mendorong terwujudnya ketahanan pangan nasional. Pendekatan penelitian yang digunakan dalam penelitian ini adalah penelitian kualitatif dengan desain penelitian deskriptif kualitatif. Subyek penelitian adalah Badan Perencana Pembangunan dan Pengembangan Kabupaten, Dinas Pertanian, Petani, Tokoh Masyarakat, Kelompok Tani di Kabupaten Lumajang,Malang, dan Blitar. Teknik sampling yang digunakan adalah Snowball sampling. Metode pengumpulan data yang digunakan adalah Dokumentasi, wawancara mendalam, observasi peran serta, dan Focus Group Dicussion (FGD). Data penelitian yang diperoleh dianalisis dengan analisis kualitatif(Content Analysis, dan Domain Analysis). Berdasarkan hasil penelitian dapat disimpulkan: 1) Terdapat keragaman profil produksi pisang, distribusi, konsumsi, dan peran kearifan lokal di Kabupaten Lumajang, Malang, dan Blitar, 2) Optimalisasi peran kearifan lokal dapat dijadikan fokus utama dalam upaya mengembangkan ketahanan pangan berbasis pisang, dan 3) Beberapa komponen penting dan strategis dalam model pengembangan ketahanan pangan berbasis pisang melalui revitalisasi nilai kearifan lokal dan penguatan kelembagaan kelompok tani adalah: a) kearifan lokal (penguatan penggunaan bahan pangan berbasis lokal, peran perempuan, peran tokoh masyarakat/agama, gotong royong, guyub rukun, desa mandiri pangan, pertanian ramah lingkungan., pertanian multikultur, dan perencanaan berbasis masyarakat), c) peran BPTP, BBMP, DUDI (pengembangan pilot projecting, permodalan, pendampingan, dan penguatan sistem produksi-distribusi-pemasaran-konsumsi).
\end{abstract}

Kata kunci: pengembangan ketahanan pangan, nilai kebijakan lokal, institusi grup petani

\begin{abstract}
This research aims to find" Food Endurance Development Model Based on Banana with Revitalisation Local Wisdom Value Reinforcement". This model serve the purpose of basis for formulate public policy and education efforts and advocation public in the field of food to push national food endurance. Approach research that used in this qualitative research with qualitative descriptive design. Subject research is bapeda, development, agriculture official, farmer, elite figure, farmer group at regency Lumajang, Malang, and Blitar. Technique sampling that used snowball sampling. Data collecting method that used documentation, indepth interview, observation participatory, and limited discussion. Research data that got to analyzed with qualitative analysis (content analysis, and domain analysis). Based on research result inferential: 1) found banana production profile unity, distribution, consumption, and local wisdom character at regency Lumajang, Malang, and Blitar, 2) local wisdom character can be made principal focus in the effort develop food endurance based on banana, and 3) several important components and strategic of food endurance development model based on banana: a) local wisdom (foodstuff use reinforcement based on local, woman character, society/religion figure character, food self-supporting village, environment friendly agriculture, agriculture multiculture, and planning based on society), b) local government character (wisdom development prima tani, pilot projecting, capitalization, assistance, and tool of productions-distributions-marketingconsumption), and c) and character BPTP, BBMP, DUDI (pilot development projecting, capitalization, assistance, and system reinforcement productions-distributions-marketing-consumption).
\end{abstract}

Key word: food endurance development models, local wisdom value, farmer group institutions

\section{PENDAHULUAN}

Ketahanan pangan mempunyai peran strategis dalam pembangunan nasional. Untuk memenuhi hal tersebut diperlukan ketersediaan pangan yang cukup setiap waktu, aman, bermutu, bergizi, dan beragam dengan harga yang terjangkau oleh daya beli masyarakat (UU No.7/1996 tentang Pangan), yang diutamakan berasal dari kemampuan sektor 
pertanian domestik dalam menyediakan bahan makanan yang dibutuhkan oleh masyarakat (PP No.68/2002 tentang Ketahanan Pangan).

Menurut Dewan Riset Nasional (2006) Permasalahan pangan yang dihadapi baik secara global, nasional, maupun lokal dapat dipilah menjadi masalah produksi, distribusi, dan konsumsi. Disisi lain, Pisang merupakan tanaman yang banyak ditanam baik sebagai komoditi komersial maupun komoditi rumah tangga untuk dikonsumsi sendiri. Tanaman pisang merupakan salah satu penghasil buah dengan luasan areal paling luas di Indonesia dibandingkan dengan tanaman buah lain. Tanaman pisang dapat ditemukan dihampir seluruh pelosok tanah air sehingga sangat potensial digunakan sebagai salah satu pilar peningkatan ketahanan pangan.

Terwujudnya kemandirian pangan, antara lain ditandai oleh indikator: (a) mantapnya ketersediaan pangan nasional, yang dicerminkan oleh impor pangan utama di bawah 10 persen dari kebutuhan pangan nasional, (b) menurunnya tingkat kerawanan pangan yang dicirikan oleh pengurangan jumlah penduduk setengahnya, yang mempunyai tingkat konsumsi pangan energi kurang dari 70 persen dari AKG (angka kecukupan gizi), (c) terpenuhinya kebutuhan pangan tingkat rumah tangga, yang direpresentasikan oleh konsumsi energi sebesar $2.000 \mathrm{kkal} / \mathrm{kap} / \mathrm{hari}$ dan konsumsi protein 52 gram/kap/hari, (d) meningkatnya keanekaragaman konsumsi pangan, dan menurunnya ketergantungan pada`satu jenis pangan tertentu pada` tingkat rumah tangga (Deptan RI, 2006). Ketahanan pangan dihasilkan oleh suatu sistem pangan yang terdiri atas tiga subsistem, yaitu : (a) ketersediaan pangan dalam jumlah dan jenis yang cukup untuk seluruh penduduk, (b) distribusi pangan yang lancar dan merata, dan (c) konsumsi pangan setiap individu yang memenuhi kecukupan gizi dan kaidah kesehatan (Deptan RI, 2006)

Di sisi lain relatif besarnya volume produksi nasional dan luas panen dibandingkan dengan komoditas buah lainnya, menjadikan buah pisang merupakan tanaman unggulan di Indonesia. Namun demikian pengelolaan pisang masih sebatas tanaman pekarangan atau perkebunan rakyat yang kurang dikelola secara intensif. Penanaman pisang berskala besar telah dilakukan di beberapa tempat antara lain di pulau Halmahera (Maluku Utara), Lampung, Mojokerto (Jawa Timur), dan beberapa tempat lainnya, sehingga Indonesia mempunyai peluang yang cukup besar untuk meningkatkan buah pisang sebagai salah satu komoditas ketahanan pangan. Hal ini ditunjang dengan ketersediaan lahan yang cukup luas di Kalimantan, Papua, kepulauan Maluku,
Sulawesi dan Sumatera; iklim yang mendukung; keragaman varietas yang cukup tinggi; sumber daya manusia serta inovasi teknologi untuk pengelolaan tanaman pisang (BPPPD Deptan, 2006, Arianti NK, 2006).

Menurut Purba (2006), Cahyono (1996), Supriyanto (1993), sentra produksi pisang di Indonesia seperti, propinsi Jawa Barat, Jawa Tengah, Jawa Timur, Lampung, Sumatera Barat, Jambi, Kalimantan, Sulawesi, Maluku, Bali, dan NTB. Bebagai jenis pisang kita jumpai seperti: Pisang raja, Pisang barangan, Pisang jambe, Pisang raja sere, Pisang kapok, Pisang Bali, Pisang mas, Pisang lampung dan sebagainya. Untuk Ekspor pisang Indonesia keluar negeri dari tahun 1999 sudah mencapai 77.472,68 ton dengan nilai US\$14.073.670. Pada tahun 2000 volume ekspor menurun, dan meningkat lagi (sedangkan volume ekspor mengalami peningkatan) pada tahun 2002 sebesar 512,27 ton senilai US $\$$ 979.730. Potensi ekspor buah pisang dapat digunakan sebagai indikator kuantitas pisang sebagai salah satu komoditas ketahanan pangan nasional.

Menurut Dewan Riset Nasional (2006) Berdasarkan permasalahan pangan yang dapat diidentifikasi, alternatif solusinya tidak selalu berupa solusi teknologi, beberapa permasalahan tersebut lebih membutuhkan solusi non-teknologi, baik berupa kebijakan publik yang mendukung atau berupa upaya edukasi publik agar dapat memahami dengan benar tentang aspek pangan tertentu. Solusi teknologi dijabarkan dalam bentuk langkah operasional berupa aktivitas riset yang relevan dan terarah untuk menjawab permasalahan-permasalahan pangan yang sedang dihadapi. Hasil riset pangan selayaknya pula digunakan sebagai acuan untuk penyusunan kebijakan publik dan/atau digunakan sebagai basis pengetahuan untuk mendukung kegiatan edukasi publik.

Dalam upaya merumuskan kebijakan publik, upaya edukasi dan advokasi publik dan strategi peningkatan ketahanan pangan berbasis pangan alternatif penganti beras sebagai dasar untuk mendorong terwujudnya ketahanan pangan nasional, maka diperlukan penemuan Model Pengembangan Ketahanan Pangan Berbasis Pisang dengan Revitalisasi Nilai Kearifan Lokal dan Penguatan Kelembagaan Kelompok Tani.

\section{METODE}

Pendekatan penelitian yang digunakan dalam penelitian ini adalah penelitian kualitatif dengan desain penelitian Fenomenologi. Subyek penelitian adalah Dinas Pertanian, Petani, Tokoh Masyarakat, 
Kelompok Tani di Kabupaten Lumajang, Malang, dan Blitar Propinsi Jawa timur. Teknik sampling yang digunakan adalah Snowball sampling. Fokus yang diteliti dalam penelitian tahun pertama ini adalah: 1) analisis produksi, distribusi, konsumsi, produk pisang, dan peran kearifan lokal, 2) analisis kebijakan pengembangan ketahanan pangan berbasis pisang, dan 3) penyusunan draft model pengembangan ketahanan pangan berbasis pisang.

Metode pengumpulan data yang digunakan adalah Dokumentasi, wawancara mendalam, observasi peran serta, dan Focus Group Dicussion (FGD). Data penelitian yang diperoleh dianalisis dengan analisis kualitatif (Content Analysis, dan Domain Analysis). Analisis isi adalah suatu teknik yang sistematik untuk menganalisis makna pesan dan cara mengungkapkan pesan. Langkah yang dilakukan pada analisis isi dalam penelitian ini menggunakan interactive model dari Miles dan Huberman (Miles \& Huberman, 1994). Model ini mengandung 4 komponen yang saling berkaitan, yaitu (1) pengumpulan data, (2) penyederhanaan atau reduksi data, (3) penyajian data, (4) penarikan dan pengujian atau verifikasi simpulan. Hasil dari analisis selanjutnya akan disajikan bentuk tabulasi silang dan narasi dari fenomena.

\section{HASIL DAN PEMBAHASAN}

Beberapa komponen penting dan strategis dalam model pengembangan ketahanan pangan berbasis pisang melalui revitalisasi nilai kearifan lokal dan penguatan kelembagaan kelompok tani adalah: 1) kearifan lokal (penguatan penggunaan bahan pangan berbasis lokal, peran perempuan, peran tokoh masyarakat/agama, gotong royong, guyub rukun, desa mandiri pangan, pertanian ramah lingkungan., pertanian multikultur, dan perencanaan berbasis masyarakat), 2) kelompok tani (penguatan managerial kelompok, peningkatan knowledge-skills, penguasaan sistem produksidistribusi-pemasaran-konsumsi, pusat informasi petani, pengembangan supproting system (hardware, software, brainware, fun, networking), 3) pemerintah daerah (pengembangan kebijakan prima tani, pilot projecting, permodalan, pendampingan, dan sarana prasana produksi-distribusi-pemasaran-konsumsi), 4) BPTP, BBMP, DUDI (pengembangan pilot projecting, permodalan, pendampingan, dan penguatan sistem produksi-distribusi-pemasaran-konsumsi) 5) produksi (pemantauan jumlah, kinerja petani, pertanian organik ramah lingkungan, ketersediaan lahan, kualitas lahan, permodalan, sentra produksi, teknik pembibitan, diversikasi produk, diversifikasi olahan, penerapan SPO, TTG, pendampingan, investor, dan penelitian), 6) distribusi dan pemasaran (akses jalan, sarana angkutan, jaringan transportasi, pasar pisang, selisih harga jual, corporate farming, pemantauan kebutuhan, daya beli masyarakat, pendampingan, investor, penelitian), dan 7) konsumsi (pola konsumsi, makanan utama, diversifikasi olahan, "gerakan tiada hari tanpa pisang", "menu utama aktivitas birokrasi dan masyarakat", pendampingan, agroindustri, eksportir, dan penelitian).

Dari tujuh komponen penting dan strategis dalam pengembangan ketahanan pangan berbasis pisang melalui revitalisasi nilai kearifan lokal dan penguatan kelembagaan kelompok tani tersebut yang menjadi lokomotif pengembangan adalah kearifan lokal dan kelembagaan kelompok tani, untuk kedua komponen ini harus dikembangan (dengan stimulasi dari pemda, dinas pertanian, DUDI, dan lain-lain) sehingga berdampak kepada komponen lainnya.

Penguatan peran kearifan lokal dalam pengembangan ketahanan pangan berbasis pisang dapat dilakukan dengan tiga cara, yaitu: 1) melestarikan budaya pemanfaatan pisang dalam even-even budaya dan tradisi, seperti untuk acara kemantenan. Menurut Priyanto (2007), lestarinya ternak di daerah Sumba karena ternak tersebut digunakan dalam even-even budaya dan tradisi. Peran ternak di Sumba sangat penting kaitannya dengan adat istiadat di Pulau Sumba sebagai "Belis" (Emas Kawin) pihak calon pengantin pria yang mencapai 20-40 ekor ternak sebagai persembahan meminang calon pengantin wanita. Maka dari itu keberadaan ternak sangat dipertahankan masyarakat. Dengan memanfaatkan momentum "kearifan lokal dan adat istiadat" tersebut membuka luas pola pengembangan ternak dengan segala konsekuensi berbasis sumberdaya lokal yang ada, 2) pengembangan kearifan lokal melalui penguatan peran dan fungsi kelompok tani.

Menurut Priyanto (2007), pembinaan kelembagaan kelompok tani dapat difokuskan dalam mengaktifkan peran dan fungsi kelompok tani, yang diarahkan pada kegiatan "gotong royong" yang merupakan keraifan lokal dalam pengolahan lahan persiapan musim hujan yang sifatnya serentak. Hal ini tersebut dilakukan karena banyak lahan petani yang belum bisa tergarap secara serenta, 3) mengembangkan manajemen produksi pengolahan skala rumah tangga dengan optimalisasi peran perempuan.

Menurut Kumoro (2009) pengolahan pisang dapat dilakukan terhadap: a). buah pisang segar yang belum masak; b). jenis pisang tertentu yang harga jualnya tergolong rendah; c). buah pisang yang kualitasnya menurun karena telah mengalami perubahan kualitas. Buah pisang yang belum masak dapat diolah menjadi keripik pisang. Dalam memotong/mengiris 
pisang untuk keripik, diperoleh sisa potongan kecil. Sisa ini dapat dikeringkan, kemudian dihancurkan menjadi tepung pisang. Buah pisang yang harga jualnya rendah dapat juga dibuat tepung pisang. Tepung pisang ini dapat diolah menjadi tempani, kue kering atau bubur untuk bayi.

Sedangkan pisang yang kelewat masak, biasanya menurun nilai jualnya, dapat dibuat poding pisang atau dodol pisang. Produk olahan yang diperoleh diharapkan dapat meningkatkan nilai jual dan pendapatan petani selaku produsen produk olahan pisang.

Dalam mengembangkan industri pengolahan pisang skala rumah perlu dibina ibu-ibu, isteri para anggota kelompok tani, yang bergabung dalam Kelompok Wanita Tani (KWT). Dalam rangka pengembangan agribisnis pisang, dapat disarankan: a) lembaga produksi bibit pisang perlu dikembangkan guna memenuhi kebutuhan akan bibit pisang bagi petani sekitarnya dan petani lain yang membutuhkannya, b) model pengelolaan kebun sehat harus selalu menjadi pedoman bagi petani yang berusahatani pisang di kebunnya, c) lembaga pemasaran yang ada diharapkan dapat bekerja sebaik mungkin, agar usahanya dapat berjalan dengan baik dan ditingkatkan peran dan kinerjanya guna membantu petani dalam meningkatkan pendapatannya, d) lembaga pengolahan hasil yang dikelola kelompok wanita tani hendaknya perlu ditingkatkan kinerjanya, agar produk olahan pisang dapat lebih dikenal masyarakat pada umumnya, e) mengingat potensi pengembangan pisang yang cukup besar, sudah selayaknya pihak-pihak yang berkompeten memfasilitasi dan mengembangkan usaha yang telah dilaksanakan kelompoktani. Pada saatnya nanti pengembangan usaha agribisnis pisang di daerah memerlukan mitra yang diharapkan dapat memfasilitasi penyediaan sarana produksi, modal dan pemasaran buah pisang segar dan produk olahannya.

Dsisi lain penguatan peran kelembagaan Kelompok Tani dalam pengembangan ketahanan pangan berbasis pisang dapat dilakukan dengan delapan cara. Pertama, pelibatan kelompok tani secara aktif dan terus menerus dalam pembangunan agropolitan. Menurut Anugrah (2003), agropolitan harus mengakomodasi dua hal utama, yaitu menetapkan sektor pertanian sebagai sumber pertumbuhan ekonomi utama dan diberlakukannya ketentuan-ketentuan mengenai otonomi daerah.

Kedua, pengembangan kelompok tani melalui model Cooperative Farming, Menurut Nuryanti (2005) model cooperative farming merupakan model pemberdayaan petani melalui kelompok dengan melakukan rekayasa sosial, ekonomi, teknologi, dan nilai tambah. Rekayasa sosial dapat dilakukan dengan penguatan kelembagaan tani, penyuluhan, dan pengembangan SDM. Rekayasa ekonomi dilakukan dengan pengembangan akses permodalan untuk pengadaan saprodi (sarana prasarana produksi) dan akses pasar.

Ketiga, pengembangan kelompok tani melalui model prima tani. Menurut Adimihardja (2006) program Prima Tani (Program Rintisan Inovasi Teknologi Pertanian), merupakan suatu konsep baru pembangunan pertanian yang bersifat "bottom up" guna mempercepat pemasyarakatan inovasi pertanian. Pendekatannya adalah mengoptimalkan pendayagunaan potensi desa secara partisipatif, bukan komando ataupun "top down".

Keempat, pengembangan kelompok tani melalui alih teknologi. Menurut Rafieq (2003), petani dengan pengetahuan lokalnya telah menemukan teknologi sederhana. Inovasi teknologi bisa dikembangkan dari teknologi sederhana yang dihasilkan petani. Kelima, pengembangan kelompok tani melalui penyuluhan. Menurut Warsana (2008), kegiatan penyuluhan tujuan akhirnya adalah menumbuhkan ketangguhan petani sebagai pelaku utama dalam pembangunan pertanian.

Keenam, pengembangan kelompok tani melalui membangun lembaga keuangan mikro berbasis komunitas petani. Menurut Hendayana (2008) percepatan adopsi inovasi memerlukan fasilitas permodalan usaha tani yang bisa diakses oleh petani dengan mudah. Hingga saat ini permodalan masih dianggap menjadi kendalanya. Di sisi lain untuk mendapatkan modal dengan mengandalkan lembaga keuangan formal yang ada, terkendala persyaratan administrasi yang tidak dapat memenuhinya sehingga peluangnya kecil. Satu-satunya sumber keuangan yang dapat diandalkan adalah lembaga jasa keuangan atau lembaga keuangan mikro (LKM) yang dikelola petani. Namun keberadaan LKM di lapangan masih terbatas jumlahnya. Mungkinkah petani masih bisa membangun LKM yang berbasis komunitas petani. LKM adalah kelembagaan usaha yang mengelola jasa keuangan untuk membiayai usaha skala mikro baik berbentuk formal maupun non formal yang diprakarsai oleh masyarakat atau pemerintah. Terdapat 7 (tujuh) prinsip yang harus dijadikan acuan ketika akan membangun LKM pertanian, yaitu: Pertama, memenuhi prinsip kebutuhan, artinya LKM pertanian hanya perlu ditumbuhkembangkan di lokasi potensial yang petaninya memerlukan dukungan fasilitasi permodalan, dan belum ada lembaga jasa pelayanan keuangan di lokasi itu. Dengan demikian LKM akan memberikan manfaat yang lebih besar bagi masyarakat setempat. Prinsip kedua adalah harus fleksibel, dalam arti LKM yang 
ditumbuhkembangkan harus disesuaikan dengan kondisi dan budaya setempat. Ketiga, harus bersifat partisipatif. Penumbuhan LKM harus melibatkan para petani di lingkungan setempat, sehingga selain dapat mengakomodasi aspirasi petani, pengembangan yang dibangun secara partisipatif akan mampu membangun rasa kepedulian dan kepemilikan serta proses melalui bekerja bersama. Prinsip keempat adalah akomodatif. Dalam hal ini LKM harus mengedepankan pemenuhan kebutuhan nasabah. Persyaratan untuk akses ke LKM disusun sedemikian rupa sehingga bisa membuka peluang seluas-luasnya untuk menjangkau kebutuhan petani dengan kelengkapan persyaratan minimal yang dimiliki petani. Prinsip kelima, adanya penguatan. Artinya, meskipun pembentukan dan pengembangan LKM bertujuan menyediakan permodalan usahatani, namun jangan sampai menciptakan ketergantungan tetapi harus mampu mendorong terjadinya penguatan kapasitas kelembagaan kelompok tani. Prinsip keenam kemitraan. Dalam hal ini pembentukan dan pengembangan LKM dilakukan dengan melibatkan berbagai pemangku kepentingan (stakeholders), seperti penyedia sarana produksi, tokoh-tokoh masyarakat tani, dunia usaha, perguruan tinggi, dan instansi sektoral terkait dalam setiap kegiatan. Prinsip yang terakhir adalah keberlanjutan. Penekanan keberlanjutan adalah pada kemampuan organisasi LKM untuk tetap terus berjalan, meskipun sudah tidak ada campur tangan lembaga atau aparat pemerintah dan swasta yang mendukungnya. LKM harus berorientasi pada tujuh fungsional menuju ke arah peningkatan perbaikan derajat kesejahteraan sosial seluruh anggota masyarakat petani (Hendayana, 2008).

Operasionalisasi pembentukan LKM dapat dilakukan melalui paling tidak enam tahap, yaitu 1) penjajagan lokasi dan pemetaan kebutuhan. Lokasi dipersyaratkan memenuhi kriteria pemerintah daerahnya kooperatif, mudah dijangkau, dan dukungan keberhasilannya tinggi, 2) Tahap seleksi kelayakan kelompok tani, 3) Tahap sosialisasi kegiatan LKM, 4) Mulai Pembentukan/ Penyusunan Organisasi LKM, 5) Tahap Operasionalisasi/ Implementasi LKM. Pada tahap ini LKM mulai memasarkan kepada masyarakat tani di sekitar wilayah itu, dan 6) Tahap akhir yaitu pengembangan LKM. Untuk dapat memudahkan pelayanan kepada nasabah (petani), maka pola yang dikembangkan adalah LKM yang memiliki kharakteristik sebagai berikut: 1) Pola pelayanannya Pola LKM Bukan Bank Bukan Koperasi (B3K), sehingga dapat bersifat sederhana, 2) Ada pinjaman kelompok tani; 3) Di samping melakukan pelayanan pinjaman pembiayaan juga menampung tabungan atau simpanan anggota kelompok; 4) Administrasi dilakukan secara sederhana tetapi tetap memenuhi syarat akuntabilitas sebagai organisasi publik; 5) Dalam upaya mendukung legalitas operasional, dibuatkan surat pengakuan berupa Surat Keputusan dari pemerintah Daerah setempat, sehingga ada jaminan hukumnya jelas (Hendayana, 2008).

Ketujuh, pengembangan kelompok tani melalui pemantapan kelembagaan pada gapoktan, Menurut Warsana (2009) Gabungan Kelompok Tani atau GAPOKTAN adalah gabungan dari beberapa kelompok tani yang melakukan usaha agribisnis di atas prinsip kebersamaan dan kemitraan sehingga mencapai peningkatan produksi dan pendapatan usahatani bagi anggotanya dan petani lainnya. Dalam upaya pemantapan Gapoktan berbagai strategi yang semestinya ditempuh adalah: Pertama. kelembagaan adalah sebuah opsi bukan keharusan. Apapun kelembagaan yang akan diintroduksikan di perdesaan, mestilah terlebih dahulu merumuskan apa kegiatan yang akan dijalankan, baru kemudian dipilih apa wadah yang dibutuhkan. Jadi, rumuskan dulu aktivitasnya, lalu tentukan wadahnya. Berdasarkan konsep sistem agribisnis, aktivitas pertanian perdesaan tidak akan keluar dari upaya untuk menyediakan sarana produksi pertanian. Kedua, sediakan waktu yang cukup untuk mengembangkan kelembagaan. Pihak pelaksana mesti mampu menyesuaikan diri dengan kelembagaan petani yang akan dikembangkan. Kesalahan selama ini adalah karena menganggap bahwa permasalahan kelembagaan ada di tingkat petani belaka, ukan pada superstrukturnya, padahal mungkin permasalahan (dan sumber permasalahan) ada pada pelaksana. Satu hal yang harus digarisbawahi sebagaimana sudah sering diingatkan adalah, agar pihak pelaksana menyediakan waktu yang cukup untuk mengembangkan sampai cukup mandiri. Masa tahun anggaran yang satu tahun tidak akan cukup untuk menumbuhkan Gapoktan menjadi mandiri. Ketiga, perlu dihindari sikap yang memandang desa sebagai satu unit interaksi sosial ekonomi yang otonom dan padu. Meskipun Gapoktan bekerja dalam satu unit desa, namun perlu dibangun jejaring sosial (social network) dengan Gapoktan lain. Relasi yang dibangun bukan bersifat hierarkhis administratif, namun lebih ke fungsional ekonomi. Dalam hal peran Gapoktan sebagai lembaga pemasaran, maka relasi jangan membatasi diri hanya dengan lembaga formal. Relasi dengan para pelaku tata niaga, yang cenderung menerapkan suasana non formal, perlu dibina dengan menerapkan prinsip saling menguntungkan dan keadilan. Keempat, Gapoktan lebih banyak berperan di luar aktivitas produksi atau usahatani, karena kegiatan tersebut telah dijalankan oleh kelompok- 
kelompok tani serta petani secara individual. Untuk terlihat dalam mekanisme pasar, maka Gapoktan harus merancang diri sebagai sebuah kelembagaan ekonomi dengan beberapa karakteristiknya adalah mengutamakan keuntungan, efesien, kalkulatif, dan menciptakan relasi-relasi yang personal dengan mitra usaha. Kelima, Gapoktan hanyalah salah satu komponen dalam pemantapan kelembagaan masyarakat perdesaan. Lebih khusus lagi, Gapoktan hanya bergerak di bidang pertanian. Dengan demikian, pemantapan Gapoktan haruslah berada dalam kerangka strategi yang lebih besar. Gapoktan hanyalah alat atau wadah untuk mencapai tujuan yang lebih besar. Pembentukan dan pemantapan Gapoktan haruslah berada dalam konteks semangat ekonomi daerah, pemberdayaan masyarakat dan penumbuhan kemandirian lokal. Gapoktan hanyalah alat dan merupakan salah satu opsi kelembagaan yang dapat dipilih. Penggunaan kelembagaan yang hanya semata-mata untuk mensukseskan kegiatan lain dan bukan untuk pengembangan kelembagaan itu sendiri, maka hanya akan berakhir dengan lembaga-lembaga Gapoktan yang semu (Warsana, 2009). Gapoktan dapat mengembangkan pisang sebagai bahan pangan pengganti karbohidrat dalam rangka diversifikasi pangan.

Kedelapan, pengembangan kelompok tani melalui kelompok pengembangan pisang sebagai bahan pangan pengganti beras dalam rangka diversifikasi pangan. Menurut Husni (2009) kebutuhan beras sebagai bahan pangan pokok terus mengalami peningkatan sejalan dengan pertambahan penduduk, disamping disamping ada masyarakat yang semula makanan pokoknya non beras beralih ke beras. Di lain pihak, lahan sawah terus mengalami penurunan sejalan terjadinya alih fungsi lahan ke non pertanian seperti untuk perumahan dan industri. Untuk mengurangi ketergantungan terhadap beras sebagai sumber karbohidrat perlu dicari bahan pangan lain sebagai sumber karbohidrat alternatif. Pisang sebagai salah satu komoditas yang dapat digunakan sebagai sumber karbohidrat alternatif karena memiliki kandungan karbohidrat dan kalori yang cukup tinggi. Akhir-akhir ini banyak muncul di berbagai mass media bahwa harga beras mengalami kenaikan cukup tinggi sehingga untuk masyarakat yang berpenghasilan rendah tidak mampu untuk membeli beras sebagai bahan pangan pokok tersebut. Kenaikan harga beras tersebut antara lain disebabkan kurangnya pasokan akibat mundurnya musim tanam dan pertumbuhan penduduk tidak seimbang dengan pertumbuhan produksi padi. Kebutuhan beras sebagai bahan pangan pokok terus mengalami peningkatan sejalan dengan pertambahan penduduk, disamping disamping ada masyarakat yang semula makanan pokoknya non beras beralih ke beras. Di lain pihak, lahan sawah terus mengalami penurunan sejalan terjadinya alih fungsi lahan ke non pertanian seperti untuk perumahan dan industri.

Dalam rangka mengurangi ketergantungan terhadap beras sebagai sumber karbohidrat perlu dicari bahan pangan lain sebagai sumber karbohidrat alternatif. Pisang sebagai salah satu komoditas yang dapat digunakan sebagai sumber karbohidrat alternatif karena memiliki kandungan karbohidrat dan kalori yang cukup tinggi. Kandungan gizi yang terdapat dalam setiap $100 \mathrm{gr}$ buah pisang terdiri dari kalori 115 kalori, protein 1,2 gr, lemak 0,4 gr, karbohidrat 26,8 gr, serat 0,4 gr, kalsium $11 \mathrm{mg}$, posfor $43 \mathrm{mg}$, besi $1,2 \mathrm{mg}$, vitamin B 0,1 $\mathrm{mg}$, vitamin C $2 \mathrm{mg}$, dan air 70,7 gr. Dengan komposisi tersebut, pisang dapat digunakan sebagai bahan pangan alternatif pengganti beras khususnya di daerahdaerah yang sering mengalami rawan pangan. Di beberapa daerah masyarakat mengkonsumsi pisang sebagai pengganti makanan pokok seperti di Sulawesi Selatan, Kalimantan Selatan, Nusa Tenggara Timur, dan Maluku (Husni, 2009).

Disamping itu pisang memiliki beberapa keunggulan dibandingkan dengan komoditas lain yaitu: 1) pisang dapat diusahakan pada berbagai type agroekosistem yang tersebar di seluruh nusantara, 2) permintaan pasar cukup besar dan produksinya tersedia merata sepanjang tahun, 3) memiliki bermacam varietas dengan berbagai kecocokan penggunaan, 4) usahatani pisang mampu memberikan hasil waktu yang relatif singkat (1-2 tahun) dan 5) disamping itu juga dapat dimanfaatkan sebagai tanaman penghijauan dan konservasi lahan karena tanaman pisang sangat baik dalam menahan air. Pisang sebagai salah satu komoditas unggulan saat ini masih tetap merupakan kontributor utama $(34,5 \%)$ terhadap produksi buah nasional. Sejak tahun 2002-2006 produksi pisang cenderung mengalami peningkatan dengan rata-rata $4,3 \%$ pertahun. Produksi pisang pada tahun 2002 sebesar 4.384.384 ton naik menjadi 5.321.538 ton pada tahun 2006 (angka prognosa) dengan produktivitas dari 58,65 ton/ha menjadi 49,45 ton/ha. Wilayah pengembangan pisang varietas Kepok terdapat di Kalimantan yaitu di Kabupaten Kota Baru, Banjar, Pontianak, Pulang Pisau, Kapuas, Kutai, Berau, dan Pasir, sedangkan di pulau Sulawesi terdapat di Kabupaten Bone, Majene, Toli-toli dan Minahasa Utara, serta sebagain besar di Nusa Tenggara Barat dan Nusa Tenggara Timur. Untuk varietas pisang Nangka terdapat di Kabupaten Simalungun, Tanah Datar, Lampung Selatan, Lampung Timur, Cianjur, dan Malang. Sedangkan pisang Tanduk banyak terdapat di Kabupaten Tapanuli Selatan, 
Cianjur, Sukabumi, Lampung Timur dan Lampung Selatan, Pandeglang, Cilacap, Lumajang, Jembrana, dan Kutai Timur. Dengan cakupan sebaran sentar produksi yang sangat luas, maka lahan yang belum dimanfaatkan dan dapat digunakan sebagai areal penumbuhan sentra produksi pisang masih tersedia sangat luas (Husni, 2009, Ernawati, 2009, Ernawati, 2008).

Mengembangkan pisang sebagai sumber karbohidrat alternatif bagi keluarga dalam rangka diversifikasi pangan disamping sebagai sumber vitamin, terutama vitamin $\mathrm{A}$ dan $\mathrm{C}$, mineral, kalsium dan zat mikro lainnya yang sangat dibutuhkan oleh tubuh manusia. Permasalahan dan kendala yang ditemui dalam pengembangan pisang khususnya pisang olahan sebagai sumber karbohidrat alternatif antara lain: a) sentra produksi pisang yang bersifat terpencar (spot) dengan skala usaha yang tidak ekonomis menyebabkan perdagangan pisang kurang berkembang dengan baik, b) tingkat produksi dan produktivitas masih rendah. Hal ini antara lain dikarenakan: petani pada umumnya belum menerapkan praktek budidaya yang baik. Sarana pengairan umumnya belum tersedia, dan serangan penyakit layu masih relatif tinggi, c) mutu produk yang dihasilkan pada umumnya sebagian besar masih kurang baik, hal ini dikarenakan: petani pada umumnya belum menerapkan pemeliharaan buah dan teknologi pasca panen yang baik dan benar (pembrongsongan buah, cara pemetikan yang benar, sortasi dan pencucian), dan keterbatasan modal petani sehingga memanen buah belum mencapai tingkat kematangan optimal, d) kelompok tani yang ada belum berfungsi dengan baik dalam mengelola kawasan kebun, e) dalam pemasaran, petani sangat sulit mendapatkan informasi pasar, baik jenis, jumlah dan waktunya, sehingga pada saat panen raya, harga pisang ditingkat petani jatuh, f) teknologi pengolahan belum tersosialisasikan sepenuhnya di lapang serta keterbatasan sarana pengolahan, dan g) beras sebagai bahan pangan pokok telah membudaya sehingga untuk beralih ke buah pisang sebagai sumber karbohidrat perlu waktu. Adanya anggapan yang keliru di masyarakat bahwa makanan pokok beras lebih bergengsi dibandingkan non beras.

Untuk mengatasi permasalahan tersebut perlu dilakukan langkah-langkah sebagai berikut. a) perlu sosialisasi bahwa pisang dapat sebagai sumber karbohidrat alternatif atau sebagai bahan pangan pokok, b) dalam upaya mendorong masyarakat menyukai pisang sebagai sumber karbohidrat diperlukan kegiatan sosialisasi penganekaragaman pengolahan makanan, c) perlu inventarisasi lahan potensial untuk pengembangan pisang, d) perlu sosialisasi teknologi budidaya dan penanganan pasca panen, serta pengolahan, e) pemberdayaan kelompok tani, dan f) fasilitasi akses permodalan bagi petani.

Pelaksanaan pengembangan pisang sebagai sumber karbohidrat alternatif perlu dukungan berbagai instansi seperti: Departemen Pertanian (Ditjen Perkebunan, Ditjen. P2HP, Ditjen PLA, Badan Litbang Pertanian, Badan Ketahanan Pangan, Setjen, Badan PSDMP), Departemen PU, Departemen Kehutanan, Departemen Kesehatan, Kementrian Koperasi dan UKM, Departemen Perhubungan, Departemen Perdagangan, Pemerintah Daerah, dan Perbankan (Husni, 2009, Wahyuni, 2009).

\section{SIMPULAN}

Berdasarkan hasil penelitian, maka dapat disimpulkan beberapa hal berikut ini: 1) terdapat keragaman profil produksi pisang, distribusi, konsumsi, peran kearifan lokal, dan peran kelembagaan kelompok tani di Kabupaten Lumajang, Malang, dan Blitar, 2) optimalisasi peran kearifan lokal dapat dijadikan fokus utama dalam upaya mengembangkan ketahanan pangan berbasis pisang dan 3) beberapa komponen penting dan strategis dalam draft model pengembangan ketahanan pangan berbasis pisang melalui revitalisasi nilai kearifan lokal dan penguatan kelembagaan kelompok tani adalah: i) kearifan lokal, ii) Pemerintah Daerah, iii) BPTP, BBMP, DUDI, iv) produksi v) distribusi, dan vi) konsumsi (pola konsumsi, makanan utama, Dari enam komponen penting dan strategis dalam pengembangan ketahanan pangan berbasis pisang melalui revitalisasi nilai kearifan lokal tersebut yang menjadi lokomotif pengembangan adalah kearifan lokal dan kelembagaan kelompok tani, untuk kedua komponen ini harus dikembangan (dengan stimulasi dari pemda, dinas pertanian, DUDI, dan lain-lain) sehingga berdampak kepada komponen lainnya. Berdasarkan hasil dan kesimpulan penelitian, maka dapat disarankan perlunya melakukan penyempurnaan draft model pengembangan ketahanan pangan berbasis pisang melalui revitalisasi nilai kearifan lokal dan penguatan kelembagaan kelompok tani. yang dilanjutkan dengan evaluasi, revisi, dan review pakar, sehingga model pengembangan ketahanan pangan berbasis pisang melalui revitalisasi nilai kearifan lokal dan penguatan kelembagaan kelompok tani.bersifat applicable.

\section{DAFTAR PUSTAKA}

Adimihardja A, 2006. Mengoptimalkan Pendayagunaan Potensi Desa. Bogor: BBP2TP, Bogor, Toid Sinar Tani, 6 Desember 2006. 
Anugrah IS, 2003. Kunci-Kunci Keberhasilan Pengembangan Agropolitan, Bogor: Puslitbang Sosial Ekonomi Pertanian Bogor, Tabloid Sinar Tani, 17 Maret 2003.

Arianti NK, 2006. Teknologi Tepat Guna Pisang: B2PTTG Subang, Kiprah Nyata LIPI yang Terpendam. Kompas 6 Juli 2006.

BPPPD Deptan, 2006. Prospek dan Arah Pengembangan Agribisnis: Pisang. Jakarta: Badan Penelitian dan Pengembangan Pertanian Departemen Pertanian.

Cahyono, B. 1996. Pisang, Budidaya dan Analisis Usahatani. Yogyakarta: Penerbit Kanisius.

Deptan RI, 2006. Revitalisasi Pertanian. http://agribisnis. deptan.go.id, 1 Januari 2007).

Dewan Riset Nasional, 2006. Agenda Riset Nasional 2006 2009. Jakarta: DRN.

Erawati TR, Surahman A, dan Fitrotin U, 2007. Budidaya Pisang Bagi Petani Miskin Di Lahan Marginal Success Story Program Peningkatan Pendapatan Petani Melalui Inovasi (P4MI), Nusa Tenggara Barat: BPTP NTB, Taloid Sinar Tani, 12 Desember 2007.

Erawati TR, Surahman A, dan Fitrotin U, 2008. Budidaya Pisang Bagi Petani Miskin Di Lahan Marginal, Nusa Tenggara Barat: BPTP NTB, Tabloid Sinar Tani, 26 Desember 2007 - 1 Januari 2008

Hendayana R, 2008. Membangun Lembaga Keuangan Mikro Berbasis Komunitas Petani, Bogor: Balai Besar Pengkajian dan Pengembangan Teknologi Pertanian (BBP2TP), Sinar Tani, 2 September 2008.

Husni I, 2009. Pengembangan Pisang Sebagai Bahan Pangan Pengganti Karbohidrat Dalam Rangka Diversifikasi Pangan, http://pfi3pdata.litbang. deptan.go.id, 9 Sept 2009.
Kumoro K, 2009. Pengkajian Sistem Agribisnis Pisang. NTB: Balai Pengkajian Teknologi Pertanian Nusa Tenggara Barat, http://pfi3pdata.litbang.deptan. go.id, 9 Sept 2009.

Nuryanti S, 2005. Model Cooperative Farming Untuk Peningkatan Pendapatan Petani, Bogor: Pusat Penelitian dan Pengembangan Sosial Ekonomi Pertanian Bogor, Tabloid Sinar Tani, 29 Juni - 5 juli 2005.

Priyanto D, 2007. Prima Tani Sumba Timur Mendukung Ketahanan Pangan Daerah. Bogor: Puslitbang Peternakan, Dimuat dalam Tabloid Sinar Tani, 5 Desember 2007.

Purba HK, 2006. Potensi Investasi Pisang di Indonesia. Jakarta: Subdit Promosi dan Pengembangan Pasar Direktorat Pemasaran Intenasional Ditjen PPHP.

Rafieq A, 2003. Mengembangkan Pengetahuan Petani Untuk Inovasi Teknologi. Kalimantan Selatan: BPTP Kalsel, Tabloid Sinar Tani, 14 Mei 2003.

Supriyanto B. dan Marsono. 1993. Rangkuman Hasil Penelitian Pisang Tahun 1989-1992. Jakarta: Prosiding Rapat Teknis Puslitbang Hortikultura di Cipanas, 23-24 Juni 1993. Pusat Penelitian dan Pengembangan Hortikultura.

Wahyuni S, 2009. Integrasi Kelembagaan Di Tingkat Petani: Optimalisasi Kinerja Pembangunan Pertanian, Bogor: Pusat Analisis Sosial Ekonomi dan Kebijakan Pertanian, Tabloid Sinar Tani, 10 Juni 2009.

Warsana SP, 2008. Strategi Melakukan Penyuluhan Pertanian Untuk Petani Kecil, Jawa Tengah: BPTP Jawa Tengah, Tabloid Sinar Tani, 9 Januari 2008.

Warsana SP, 2009. Pemantapan Kelembagaan Pada Gapoktan, Jawa Tengah: BPTP Jawa Tengah, Tabloid Sinar Tani, 8 April 2009. 